\title{
Good Governance of Great Resources To Great Social Well Being In Indonesia
}

\author{
Martono Anggusti \\ Faculty of Law, HKBP Nommensen University Medan - Indonesia \\ martono.pang@gmail.com
}

\begin{abstract}
There are 17,504 islands that are included in the territory of the sovereign state of the Republic of Indonesia according to the Deputy of Maritime Sovereignty of the Coordinating Ministry for Maritime Affairs, where 16,056 islands have been standardized at the United Nations until July 2017. There are more than 300 ethnic groups in Indonesia, or precisely 1,340 tribe according to the 2010 Central Statistics Agency census. There are 6 religions recognized in Indonesia, namely Islam, Protestantism, Catholicism, Hinduism, Buddhism and Confucianism. With so many tribes, cultures, resources and the nature beauty. Who is not proud to be born in Indonesia. A gift from God that has no two in this world, that is the country of Indonesia and known as the world's paradise. On tuesday, January 29, 2019, the manager of transparency international Indonesia Research, Wawan Sujatmiko, said the score of Indonesia's GPA rose by one point. "The Indonesian GPA score of 2018 is 38, after 2016, 2017 is a score of 37 GPA." The "sheepfighting" culture left behind by the Dutch colonials still prevails. The law "blunt up" and "sharp down." Soekarno, Indonesia's first president once said that "My struggle is easier because it expels invaders, your struggle will be more difficult because it is against your own people." Maybe when just reach independence, this sentence will be difficult to understand. But today, the history proves it.
\end{abstract}

Keywords: Four pillars of Nationality, Welfare state, Law enforcement, Education, love the country.

\section{Introduction}

There are three stages of development in a country, starting from developing countries to becoming developed countries, namely: 1st stage, start from UNIFICATION, focus on how to achieve political integration and create national unity; 2nd stage, INDUSTRIALIZATION, focus to the struggle for economic development and political modernization; and the 3rd stage, SOCIAL WELFARE, concern to how the state primarily protect the people from the negative side of industrialization, correcting mistakes in the previous stage, with the main focus of people's welfare. The law has a very important position in efforts to be able to provide conditions that can spur development economy and to maintain relations between various elements and economic actors. The role of law in the economic development of a country is basically inseparable from discussions about the economic approach to the law or vice versa, the legal approach to the economy, commonly known as 
economic analysis of the law. The economic approach to law means the use of economic considerations to solve problems, and the use of tools or concepts of analytical techniques commonly used by economists. The approach to legal economics is and uses transnational and interdisciplinary approaches, specializing in the relationships between economic problems and national and regional and international social integrals. There are at least five legal qualities that are conducive to development planning and implementation, namely: stability (predictability), fairness, education (education, development of the legal profession (the special development abilities) of the lawyer).

4 Pillars of Indonesian Nationality, namely: (1) Pancasila, (2) 1945 Constitution, (3) Unity in Diversity, (4) Unitary State of the Republic of Indonesia (NKRI).

And Pancasila is the basic ideology in life for the Indonesian state. The name consists of two Sanskrit words: pañca means five and śila means principle. Pancasila is the formulation and guideline of national and state life for all Indonesian people. The five main joints of the constituents of Pancasila are (1) The One Almighty God; (2) Just and civilized humanity; (3) Indonesian Unity; (4) Democracy led by wisdom in consultation / representation; and (5) Social justice for all Indonesian people. Pancasila is listed in the 4th paragraph of the Preambule of the 1945 Constitution. On June 1st, the anniversary of Pancasila was celebrated.

The 1945 Constitution of the Republic of Indonesia Chapter I Form and Sovereignty Article 1 paragraph 3 states that the Indonesian State is a state of law. Article 27 paragraph 2 states: Every citizen has the right to work and a decent living for humanity. Article $28 \mathrm{C}$ paragraph 1 states that everyone has the right to develop themselves through the fulfillment of his basic needs, the right to education and to benefit from science and technology, arts and culture, for the sake of improving his quality of life and for the welfare of humanity. Article 28E paragraph 1 Everyone has the right to embrace religion and worship according to his religion, choose education and teaching, choose work, choose citizenship, choose a place to live in the territory of the country and leave it, and the right to return. Article $28 \mathrm{H}$ paragraph 1 Everyone has the right to live in physical and spiritual prosperity, to live and to have a good and healthy living environment and the right to obtain health services. Paragraph 3 Every person has the right to social security which enables his or her full development as a dignified human being. Article 28I paragraph 4 Protection, promotion, enforcement and fulfillment of human rights is the responsibility of the state, especially the government. Chapter XIII Education and Culture Article 31 paragraph 1 Every citizen has the right to education. Paragraph 4 The State prioritizes the education budget of at least twenty percent of the state income and expenditure budget and from the regional income and expenditure budget to meet the needs of the national education administration. Chapter XIV National Economy and Social Welfare, Article 33 paragraph 1 The economy is structured as a joint effort based on the principle of 
kinship. Paragraph 3 The earth and water and the natural resources contained therein shall be controlled by the state and used for the greatest prosperity of the people. Article 34 paragraph 1 The poor and neglected children are cared for by the state. Paragraph 2 The state develops a social security system for all people and empowers people who are weak and unable to comply with human dignity. Paragraph 3 The State is responsible for the provision of adequate health service facilities and public service facilities.

Bhinneka Tunggal Ika is the motto of the Indonesian people written on the symbol of the Indonesian state, Garuda Pancasila. This phrase comes from the Old Javanese language which means "Different but still one".

Translated per word, the word bhinneka means "diverse". The word neka in Sanskrit means "kind" and forms the word "various" in Indonesian. The single word means "one". The word ika means "that". Bhinneka Tunggal Ika is literally translated "Diverse One That", which means that although diverse, in essence the Indonesian people are still one entity. This motto is used to describe the unity of the Nation and the Unitary State of the Republic of Indonesia which consists of diverse cultures, regional languages, races, ethnic groups, religions and beliefs.

The Republic of Indonesia (RI) or the Unitary State of the Republic of Indonesia (NKRI), or more commonly called Indonesia, is a country in Southeast Asia that is crossed by the equator and is between the continents of Asia and Australia, and between the Pacific Ocean and the Indian Ocean. Indonesia is the largest archipelago country in the world consisting of 17,504 islands. An alternative name commonly used is the archipelago. With a population of nearly $270,054,853$ people in 2018 , Indonesia is the fourth most populous country in the world and the country with the largest Muslim population in the world, with more than 230 million people. The form of the state of Indonesia is a unitary state and the form of government of Indonesia is the Republic, with the House of Representatives, the Regional Representative Council and the President directly elected by the people.

Indonesia is the country with the second highest level of biodiversity in the world after Brazil. This fact shows the high diversity of biological natural resources owned by Indonesia and this, based on the Nagoya Protocol, will be the backbone of sustainable economic development (green economy). The Nagoya Protocol itself formulates the equitable distribution of access and distribution of benefits between the manager and the country that owns the natural resources, and includes an explanation of the mechanism for utilizing the natural resource wealth. Indonesia's abundant natural wealth is formed by several factors, including: 1. In terms of astronomy, Indonesia is located in a tropical area that has high rainfall so that many types of plants can live and grow quickly; 2. In terms of geology, Indonesia is located at the point of tectonic plate movement so that many mountains are rich in minerals; 3 . 
Water areas in Indonesia are rich in food sources for various types of plants and marine animals, and also contain various types of mineral sources.

The high level of biodiversity in Indonesia is indicated by the presence of $10 \%$ of the world's known flowering plants can be found in Indonesia, $12 \%$ of mammals, $16 \%$ of reptile animals, $17 \%$ of birds, $18 \%$ of coral reef species, and $25 \%$ of marine animals . In the field of agriculture, Indonesia is also famous for the wealth of its plantation crops, such as cocoa beans, rubber, palm oil, cloves, and even wood, many of which occupy the top ranks in terms of its production in the world.

Natural resources in Indonesia are not limited to their biological wealth. Various regions in Indonesia are also known as producers of various types of mining materials, such as petroleum, tin, natural gas, nickel, copper, bauxite, tin, coal, gold, and silver. In addition, Indonesia also has fertile soil and is good for various types of plants. The waters which reach 7.9 million $\mathrm{km} 2$ also provide enormous natural potential.

President Joko Widodo (Jokowi) emphasized that Indonesia's human resources (HR) have the ability to compete with other countries. It is only recognized by the President that this power has not yet been maximized in its potential.

This was conveyed by the President when giving a speech at the handover of the Apprenticeship Competency Certificate to apprentice program participants at the Center for Job Training Development (BBPLK) Bekasi, West Java, the President said, that $60 \%$ of young children of the productive age is the strength. "This is our wealth, and this is our chance to win the competition in competing with other countries. If we can manage, if we can exploit this potential, if we can exploit this, we will become a winning nation, "said President Jokowi.

On the occasion, the President reminded that the competency certificate was very important, because it was clearly tested in what field of competence. He pointed to the example for matters in the front office that can be taken anywhere, which shows that they have been trained to be able to serve in the front office.

President Joko Widodo's speech. Vision of Indonesia for the next 5 years at the Sentul International convention center Bogor on July 14, 2019:1. Infrastructure development continues;2. Priority of Human Resources development since in the womb;3. Simplify investment in employment;4. Bureaucratic reform;5. The State Budget must be on target.

The development of automation, internet of things, big data and artificial intelligence provides many opportunities and new choices for business people in running their businesses and also for consumers in determining their choices. This was stated by 
Minister of Finance Sri Mulyani Indrawati at the KADIN Entrepreneurship Forum at the Shangri-La Hotel, Jakarta.

On that occasion, the Minister explained that Indonesia's readiness in facing the 4.0 industrial revolution which was one of the indicators seen in the Global Competitiveness Index issued by the World Economic Forum (WEF). In 2018 Indonesia was in the 45th position in the world, up from 47 in 2018. Meanwhile, for the ASEAN region, Indonesia sits at 4th place below Singapore, Malaysia and Thailand. This is a challenge for the Indonesian people to immediately grade. The World Economic Forum also released 12 components to measure the readiness of a country to enter the industrial era 4.0 with their respective rankings in 2018 ago. Indonesia's ranking in each of these components is 48 for institutional development, 71 for infrastructure, 50 for ICT adoption, 51 for macro economic stability, 95 for health, 62 for skills, 51 for product market, 82 for labor market, 52 for financial system, 8 for market size, 30 for business dynamism, and 68 for innovation capability. Include program of fiscal policies to support Indonesia's readiness to enter the industrial era 4.0 including the development of digital infrastructure and continuing with the development of the national optical fiber network of Palapa Ring. Until now, 35,280 km of submarine cable and 21,807 $\mathrm{km}$ of land cable have been realized.

In addition, according to the Minister of Finance improving the quality of Human Resources (HR) is also needed. This is done by providing government scholarships through the Government Fund Management Institute (LPDP) which has reached 20,255 scholarship recipients, improving health and social security for the community by providing a Healthy Indonesia Card (KIS) which reaches 96.8 million, and efforts to increase the percentage of availability drugs and vaccines in health centers by $95 \%$ in 2019. The Minister of Finance also issued Minister of Finance Regulation (PMK) No. 150 / PMK.010 / 2018 concerning the Provision of Corporate Income Tax Reduction Facility to follow up on one of the points in the XVI Economic Policy Package which is expanding tax holiday facilities to encourage direct investment. The customs incentive scheme is also carried out in the context of trade facilitators to increase investment and encourage economic growth.

Minister of Manpower M Hanif Dhakiri reminded the importance of developing Human Resources (HR) through investment in human resources in Indonesia. The availability of reliable human resources must be prioritized together to meet the demand for skilled workers in accordance with the industrial world.

"The apprenticeship program is one of the efforts to prepare competent workforce and in accordance with industry needs. In addition, apprenticeship also accelerates the absorption of unemployment to enter the workforce, "said Menaker Hanif when attending the National Vocational Committee and Regional Vocational Committee 
Coordination Meeting at the PT. Toyota Motor Manufacturing Indonesia (TMMIN).

The Ministry of Manpower targets to be able to hold apprenticeship programs for 400,000 people supported by the Chamber of Commerce and Industry (KADIN), the Indonesian Employers' Association (APINDO) and related industries. To achieve this target, the MoM must prepare at least 8,000 mentors from industries.

MoM Hanif said that in carrying out the apprenticeship program, the government needed the support of relevant stakeholders. Apprenticeship was the beginning to create a role model for vocational training that suited industry needs.

\section{Findings And Conclusions}

1. Indonesia's dominant population with low education is very vulnerable to politicization.

2. The Indonesian people are now more obsessed with embracing the principles of liberalization, the individualist principle and the capitalist principle.

3. Indonesia is a country that is rich in human and natural resources.

4. Indonesia has a Pancasila ideology that is quite complete and fantastic like no other in the world.

5. Indonesia is a pluralist and unique country in diversity that is second to none in the world.

6. Indonesia has brilliant human resources in other countries who are ready to go home if needed.

7. Indonesia has a culture that lives in harmony with the principles of kinship, togetherness and mutual cooperation.

8. People's welfare is the goal of the Indonesian state as stated in the 1945 Constitution.

9. The Nawacita program is a government program that is on time and on target and is run by a government that is clean and has a people's heart.

10. The SDGs program is in tune with current government programs and is carried out towards a clean and responsible government.

11. The real work shown by the government in achieving Indonesia's dream of becoming the 7 th country in 2030 .

\section{Recommendations}

1. Education in schools since kindergarten puts more emphasis on morals and ethics.

2. Nawacita program is the right things to implement.

3. Mental revolution needs to be emphasized and carried out seriously. 
4. Political problems must be resolved by applying strict law, the law is the commander.

5. The moderated CSR program is more emphasized in helping government programs accelerate people's welfare.

6. Government programs in building the people's economy through small and medium businesses / SMEs can be entrusted to corporate CSR.

7. Law enforcement needs to be changed by minimizing imprisonment but more on impoverishment and seizure of family property or related, so that families participate in supervising the behavior of each individual in each family.

8. Indonesia is a bonus for its people, it only takes awareness of the Indonesian people themselves how to make the best use of it as a pluralist nation.

9. Remember the statement of the $1^{\text {st }}$ President: "My struggle is easier because it expels invaders, your struggle will be more difficult because it is against your own people."

10. Love Indonesia and Implement the principle of kinship, togetherness and mutual cooperation, let's built Indonesia by heart.

\section{REFERENCES}

Alvi Syahrin, Martono Anggusti, Abdul Aziz Alsa (2018), Hukum Lingkungan di Indonesia: Suatu Pengantar, Jakarta Timur: Prenadamedia Group.

Bob Tricker (2012). Corporate Governance Principles, Policies, and Practices, Hampshire: Ashford colour Press Ltd.

John Elkington (1999). Cannibals With Forks, United Kingdom: Capstone Publishing Limited.

Kevin Wilhelm (2013). Return On Sustainability, New Jersey: Pearson Education, Inc.

Klaus Schwab (2017). The Fourth Industrial Revolution, Great Britain: Clays Ltd, St Ives plc

Martono Anggusti (2019), Pengelolaan Perusahaan \& Kesejahteraan Tenaga Kerja, Jakarta: Bhuana Ilmu Populer.

Muhannad Junaidi. (2013). Korporasi dan Pembangunan Berkelanjutan. Bandung: 


\section{Penerbit Alfabeta.}

https://id.wikipedia.org/wiki/Pancasila, diakses tgl. 6/8/2019.

https://id.wikipedia.org/wiki/Bhinneka_Tunggal_Ika, diakses tgl.6/8/2019.

https://id.wikipedia.org/wiki/Indonesia, diakses tgl. 6/8/2019.

https://www.neliti.com/id/publications/9230/peran-hukum-dalam-pembangunanekonomi, diakses tgl.25/8/2019.

https://id.wikipedia.org/wiki/Sumber_daya_alam, diakses tgl.26/8/2019

https://www.liputan6.com/news/read/4013281/headline-5-tahapan-jokowi-wujudkanindonesia-maju-mana-paling-

prioritas?utm_expid=.9Z4i5ypGQeGiS7w9arwTvQ.0\&utm_referrer=https\%3A $\% 2 \mathrm{~F} \% 2 \mathrm{Fwww}$.google.com.sg\%2F, diakses tgl.26/8/2019. 